\title{
Rissschaden an einem Messing-Fitting \\ Crack Damage in a Brass Fitting
}

Dusan Grman, Markus Zgraggen

(Eidg. Materialprüfungs- und Forschungsanstalt, Dübendorf, Schweiz)

\section{Kurzfassung}

Durch metallkundliche Untersuchungen konnte geklärt werden, dass das defekte Messing-Fitting infolge Spannungsrisskorrosion (SpRK) im Winkelkniebereich undicht geworden ist. Als wesentlich schadensbegünstigend muss der im Bereich der Fitting-Einschraubzone festgestellte und als ausgeprägte $\mathrm{SiO}_{2}$-Schlackeneinschlüsse identifizierte Materialfehler angesehen werden, der zu einem vorbestandenen Anriss führte. Die Spannungserhöhungen an der rissartigen Fehlstelle gaben im weiteren Anlass zur Initierung de SpRK. Der vorliegende Schadensfall stellt somit ein typisches Beispiel für eine Kumulation mehrerer Schädigungsmechanismen dar.

\section{Schadensbild}

Zur Untersuchung wurde ein undicht gewordenes Messing-Fitting aus Ms58 mit einem in das Fitting eingeschraubten Messing-Nippel eingeliefert. Der defekte Messingteil führte durch sein Versagen zu einem grossen Wasserschaden in einem Einfamilienhaus. Die fragliche Leckstelle solite sich außerhalb der Fitting-Einschraubzone und zwar im Winkelkniebereich befinden, wo rein visuell keine Rissbildung festzustellen war. Demgegenüber lassen die Fittingpartien im Bereich der Nippel-Einschraubzone einen makroskopisch deutlich sichtbaren, bogenförmig verlaufenden Anriss erkennen (Bild 1). Der insbesondere Aniss erkennen (Bld 1). Der insbesondere im Bereich der Silmache stark klaffende Anriss weist eine Länge von ca. $13 \mathrm{~mm}$ auf. Aufgrund der Rissausbildung kann vermutet werden, dass es sich hierbei um einen vorbestandenen Anriss handelt.
Abstract

A metallurgical investigation revealed that a defect found in the bend of a leaking brass fitting was a result of stress corrosion cracking (SCC). The principal cause of the failure is shown to be the presence of significant $\mathrm{SiO}_{2}$-inclusions found in the threaded part of the fitting which led to preexisting crack. The increase in stress at this crack-like defect led to the initiation of SCC. The failure is a typical example of the cumulative action of a number of damage mechanisms.

\section{Visual Inspection}

A leaking brass fitting made of the alloy Ms58, into which was screwed a brass nippel, was submitted for investigation. The failure of the defective brass component resulted in considerable water damage being done to a residential property. The leak was reported to be in the angled part of the fitting away from the threaded nipple insert, at a place where no cracking was actually visually apparent. A clearly macroscopically visible curved crack was however found where the nipple was screwed into the fitting (Fig.1). The widely gaping crack, particularly on the top surface, had an overall length of ca. $13 \mathrm{~mm}$. The visual an of the crack suggested that it had been present some time prior to the actual failure of the fitting.

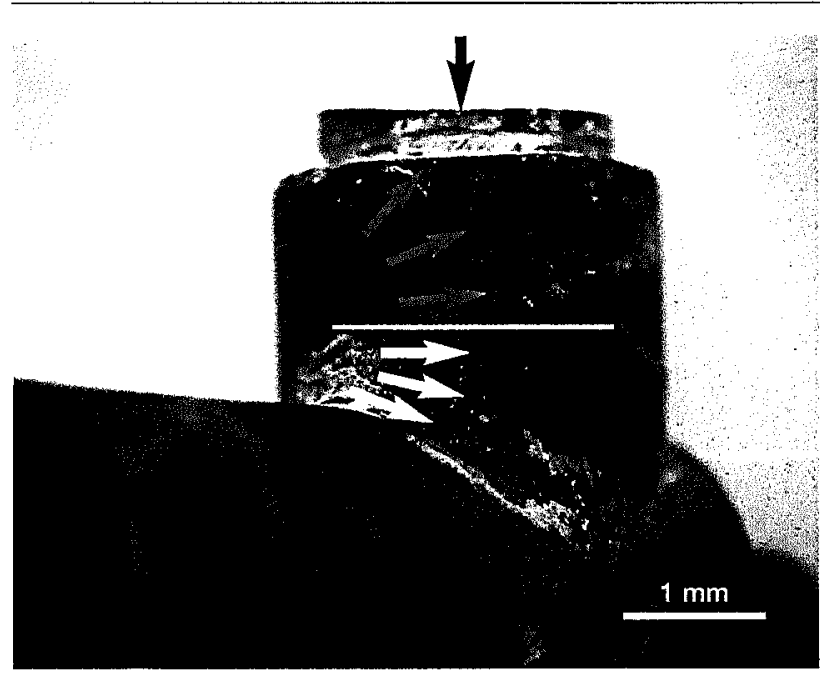

Bild 1. Teilansicht des defekten Messing-Fittings. Rote Pfeile: Vorbestandener, bogenförmig verlaufender und im Bereich der Stirnfläche stark Klaffender Anriss in der Fitting-Einschraubzone. Weiße Pfeile: Durch Spannungsrisskorosion geschädigte Fittingpartie, die sich bis in den Winkelkniebereich erstreckt. Weiße Linie: Ende des eingeschraubten Messing-Nippels, dessen Lage etwa der Übergangszone zwischen dem vorbestandenen Anriss und der durch Spannungsrisskorrosion geschädiglen Fingpartie entspricht. Schwarzer Pleil. Messing-Einschraubnippel.

Fig. 1. Detail of the defective brass fitting. Red arrow: Existing curved and gaping crack in the female threaded part of the fitting. White arrow: Part of the fitting damaged by stress corrosion cracking which extends into the angled part of the fitting. White line: The end of the brass nipple, the position of which damaged by stress corrosion cracking Black arrow: The brass nipple.

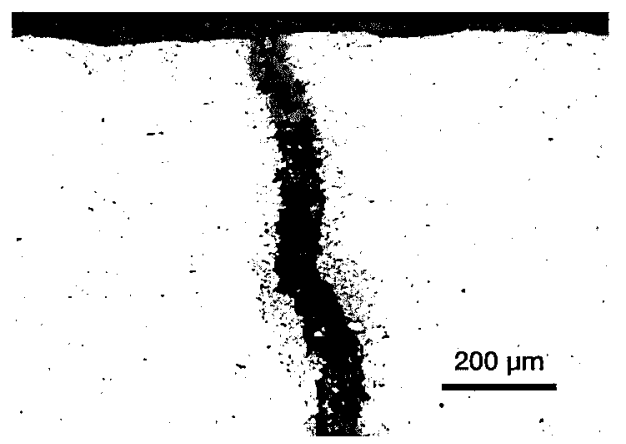

Prakt. Metallogr. $37(2000) 2$
Bild 2. Bereich der Fitting-Einschraubzone: Vorbestandener stark klaftender Anriss mit ausgeprägten Schlackeneinschlüssen auf der Fittingwand-Aussenseite (ungeätzt)

Fig. 2. The threaded part of the fitting: Pronounced widely gaping crack with heavy inclusions to the outside wall of the fitting. (unetched). 

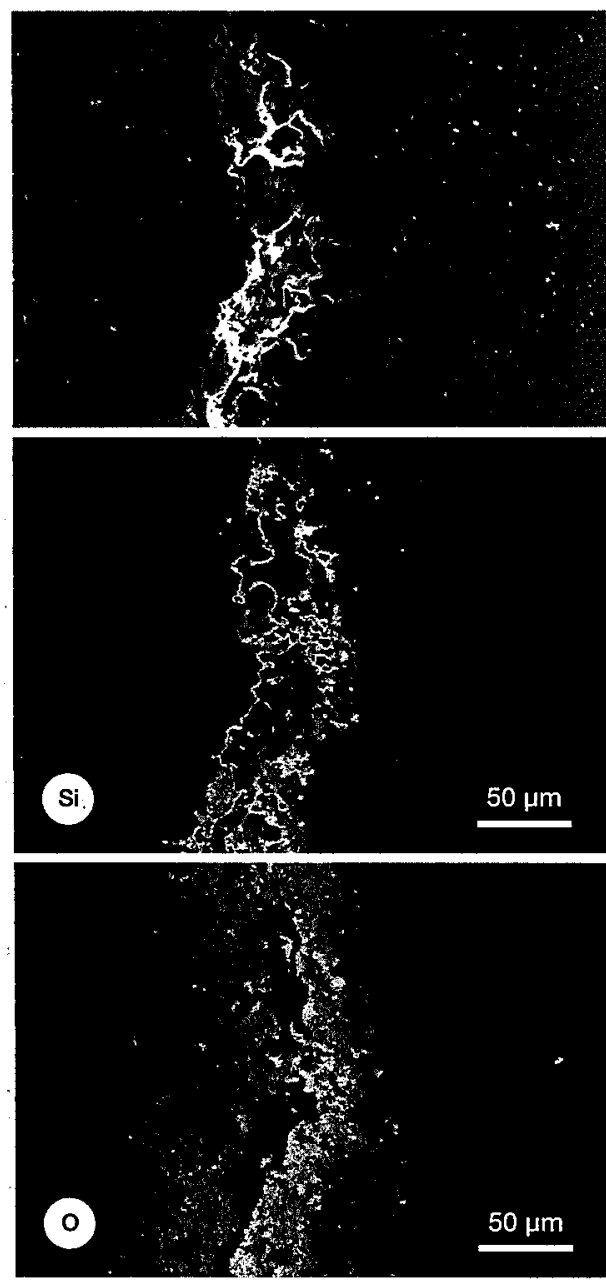
Bild 3. Rasterbild sowie Röntgenverteilungsbilder
von Silicium und Sauerstoff: Vorbestandener Anriss mit ausgeprägten, aus $\mathrm{SiO}_{2}$ aufgebauten Schlackeneinschlüssen, ausie Enzinkungserscheinungen im Bereich der Fitting-Einschraubzone Fig. 3. Scanning electron micrograph and $X$-ray
maps of the distribution of silicon and oxygen: Pronounced crack with heavy $\mathrm{SiO}_{2}$ slag inclusions and the appearance of dezincification in the threaded part of the fitting.

\section{Experimentelle Untersuchung}

Die metallographische Untersuchung von mehreren Querschliffproben hat bestätigt, dass im Bereich der Fitting-Einschraubzone ein vorbestandener, stellenweise durchgehender und durch ausgeprägte Schlackeneinschlüsse bzw. feine Enzinkungserscheinungen gekennzeichneter $A n-$ riss vorliegt (Bild 2). Die vorgefundenen, z.T. grob ausgebildeten und mikroanalytisch als $\mathrm{SiO}_{2}$ iden-

\section{Experimental Investigation}

The metallographical examination of a number of cross sections confirmed the threaded nipple insert to contain a pre-existing crack, in parts penetrating the full thickness of the wall of the fitting, together with significant, large slag inclusions and slight signs of dezincification (Fig. 2). The slag inclusions, some of which were quite coarse and

Prakt. Metallogr. 37 (2000) 2 therefore a severe defect in the material, were

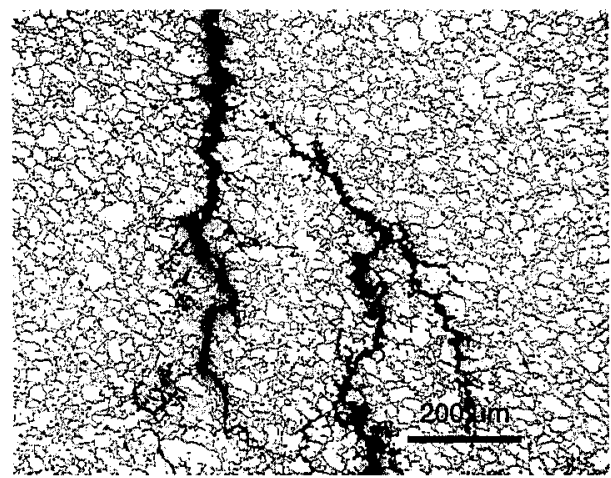

Bild 4. Winkelkniebereich: Stark verzweigte, inte kristallin verlaufende Spannungskorrosionsriss mit feinen Verästelungen (geätzt)

Fig. 4. Angled part of the fitting: Heavily branched, intercrystalline stress corrosion cracks with finer branches (etched).

tifizierten Schlackeneinschlüsse (Bild 3) müssen als gravierender Materialfehler angesehen werden. Eine weitere mikroskopische Untersuchung ergab, dass der vorbestandene Anriss etwa im Bereich des Nippelendes in eine durch Spannungsrisskorrosion geschädigte Fittingpartie übergeht. Wie das Bild 4 zeigt, wurden im Winkelkniebereich typische stark verzweigte und mehrheitlich mit Korrosionsprodukten gefüllte Spannungskorrosionsrisse festgestellt, die einen interkristallinen Rissverlauf aufweisen. Aufgrund des Verlaufs der Rissverzweigungen konnte abgeklärt werden, dass der Spannungskorrosionsriss von der Fittingwand-Außenseite ausgegangen ist. Das Gussgefüge des Schadenobjektes entspricht einem relativ feinkörnigen $(\alpha+\beta)$-Messing mit zahlreichen feinen Bleieinschlüssen. sing mit zanteichen feinen Bleinschussen Extreme Kallverformungsmerkmale an den Gewindeflanken des Fittings bzw. des Einschraub-
nippels, welche auf Montagefehler hindeuten würden, wurden nicht festgestellt.

Bei der fraktographischen Untersuchung wurde festgestellt, dass die im Winkelkniebereich freigelegte Anrissfläche einen interkristallinen Bruchverlauf mit klaffenden Kornflächen bzw. festhaftenden Korrosionsprodukten aufweist (Bild 5). Die vorgefundenen Korrosionsprodukte wurden

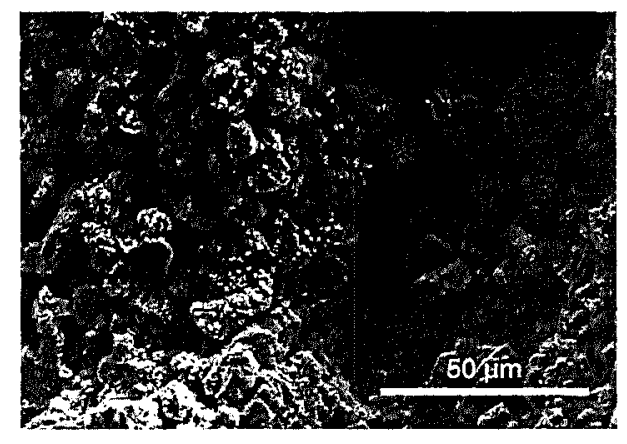
Bild 5. Bruchmikrotopographie im Winkelkniebe-
reich: Interkristalliner Bruchverlauf mit klaffenden Kornflächen sowie festhaftenden Korrosionsprodukten

Fig. 5. Fracture surface in the angled part of the fitting. Fracture surace in the angled part of the grain boundaries and strongly adhering corrosion products.

micro-analysed and found to be $\mathrm{SiO}_{2}$ (Fig. 3). A further microscopic examination of the crack revealed that close to the end of the nipple the crack ran into a part of the fitting damaged by stress corrosion cracking. As can be seen from Fig. 4, heavily branched intercrystalline cracks, mostly filled with corrosion products, were found in the angled part of the fitting. This type of crack is cracking. The path of the crack branching indicated the crack to have started in the outside surface of the wall of the fitting. The cast microstructure of the component was typical of a relatively fine grained $(\alpha+\beta)$ brass containing numerous fine inclusions of lead. No signs of extreme cold deformation could be found either on the sides of the thread of the fitting or on the nipple, which might have indicated mechanical abuse during assembly.

An scanning electron micrograph (Fig. 5) of the inner surface of the crack in the angled part of the fitting revealed an intercrystalline mode of fracture with gaping grain boundaries and strongly adhering corrosion products. The corrosion products were subsequently analysed by electron 
anschließend mit der Elektronenstrahl-Mikro- beam micro-analysis to determine the possible sonde auf Anwesenheit von korrosiv wirkenden presence of corrosive substances, and in particuStoffen geprüft. Es wurde insbesondere nach lar nitrogen, as nitrogen-containing compounds Stickstoff gesucht, da stickstoffhaltige Verbindun- are known to initiate stress corrosion cracking in gen Spannungsrisskorrosion an Messingteilen brasses. The results of the micro-analyses ultianalyti- mately revealed the corrosion products to contain schen Prüfung konnte bestätigt werden, dass in considerable accumulations of nitrogen-contaiden untersuchten Korrosionsprodukten erhebli- ning compounds.

che Stickstoffanreicherungen vorliegen.

\section{Zusammenfassung und Beurteilung}

Die Untersuchung hat ergeben, dass das defekte Messing-Fitting infolge Spannungsrisskorrosion im Winkelkniebereich undicht geworden ist. Messingwerkstoffe sind bekanntermassen spannungsrisskorrosionsempfindlich. Dazu müssen gleichzeitig Zugspannungen und spezifische Angriffsmedien (insbesondere stickstoffhaltige Verbindungen wie Ammoniak, Stickstoffdioxide, Nitrate etc.) auf das Messingbauteil wirken. Als aggressive Stoffe konnten auf der freigelegten Anrissfläche mikroanalytisch erhebliche Mengen von stickstoffhaltigen Verbindungen nachgewiesen werden. Der metallographische Befund ergab, dass der festgestellte Spannungskorrosionsriss im Bereich des vorbestandenen Materialehlers aufgetreten ist und sich in der gleichen Fen bis in den Winkelkniebereich forpfanzte. Als auslösenc Als auslösende Zugspannungen wirkten somit die lokalen Spannungserhöhungen an der rissartigen Fehlstelle. Als wesentlich schadensbegünstigend muss folglich der festgestellte Materialfehler angesehen werden, der Anlass zur Initierung der SpRK gab. Zwar ist der vorbestandene Anriss stellenweise durchgehend; da ieloch Ans defelte Fiting im Bereich der Nippedoch das defekte Fing im Bereich der NippelEinschraubzone durch Hanffäden abgedichte wurde, konnten im vorliegenden Fittingbereich keine Undichtheiten enstehen.

\section{Summary and Conclusion}

The investigation revealed the leakage in the angled section of the defective brass fitting to have been caused by stress corrosion cracking. Brasses are well known to be sensitive to stress corrosion cracking. For this to occur, tensile stresses together with a specific corrosive medium (in particular nitrogen-containing compounds such as ammonia, nitrogen dioxide, nitrates, etc.) mus both act simultaneously on the brass component. As evidence of the presence of an aggressive medium, considerable quantities of nitrogen-containing compounds were found by micro-analysis on the surface of the crack. The metallographical examination revealed that the stress corrosion crack initiated in the region of an existing material defect from which it grew in the same plane into the angled part of the fitting. The tensile stresses required to initiate the stress corrosion cracking were present in the form of localised interna stresses within the part of the fitting containing the crack-like defects. The principal cause of failure must therefore be attributed to the presence of these defects which ultimately initiated the stress corrosion cracking. Whilst it is true that the existing wall of the filling, the hemp caulking used to assemble the nipple into the fitting would have prevented any leakage at this point.

Angenommen: 26. Mai 1999

Accepted: May 26, 1999

Korrespondenzanschrift/Correspondence address: Eidg. Materialprüfungs- und Forschungsanstalt, Überlandstr. 129, CH-8600 Dübendorf, Schweiz; e-mail: dusan.grman@empa.ch

\section{Sehen - Verstehen - Gestalten}

Dietrich Schulze

Mikrostrukturen im Elektronenmikroskop Werkstoff-Informationsgesellschaft $\mathrm{mbH}$ Frankfurt 1998

216 Seiten, ISBN 3-88355-260-7

Preis $78,-D M$

Die Besprechung dieses Buches macht Spaß: Wer von den Lesern der praktischen Metallographie dieses hervorragend aufgemachte Werk über die mikroskopische Struktur von Kristallen und die Verfahren zur Abbildung noch nich kennt, soltte es sich so bald wie möglich ansehen Hier hat ein berūhmter Kollege viel der in seinem Arbeitsleben gemachten Erfahrungen in eine Weise zusammengestellt, die präzise Information mit künstlerischer Ästhetik so verbindet, das das Lesen zum staunenden Schauen und das Schauen zum tiefen Verstehen führt. Es geht um Strukturen, die in der belebten und in der unbelebten Welt auftreten und die mit mikroskopischen Techniken, vor allem mit dem Elektronenmikroskop, sichtbar werden. Der Autor verbinde das physikalische und biologisches Wissen, mit dem er dem Leser Einblick in die Wirkungsweise der abbildenden Geräte und der Bauprinzipien von weit voneinander unterschiedlich erscheinenvon well voneinander unterschiedich ersch den Strukturen wie Schrauben und Seesternen Muskelfasern und Versetzungen, Kristallen un Blättern gibt, mit hoher künstlerischer und humanistischer Bildung, die eine Zuordnung von Unbekanntem zu Bekanntem, und die Herstellung von Verbindungen zwischen technisch- naturwissenschaftlichen Tatsachen und intuitiver Anschaulichkeit ermöglicht bzw. fordert.

Die einzelnen Abschnitte des Textteils sind mit zum Lesen anregenden Überschriften versehen, so z.B. "Von den Reizen der Kristallstrukturen", Das Elektronindividuum mit zwei Gesichtern "Teilchen oder Welle?", „Die närrische Struktur der Teilchen oder Welle?", ,Die närrische Struktur der "Grenzen der Wahrnehmung" oder "Gitter, Maschen, Netzte" versteht es der Autor, Geschichte und Geschichtchen mit konkreten Informationen zu einem Text zu verbinden, der ebenso im Lehnstuhl eventuell bei einem Glas Wein wie als willkommene Unterbrechung des Tagesgeschäfts in

Prakt. Metallogr. 37 (2000) 2 der Studierstube genossen werden kann. Das trifft in noch starkem Maß für den Bildteil zu, wo - ebenfalls wurde unter spannenden Titeln zusammengefasst - eine Vielzahl von optischen Eindrücken exzellenter mikroskopischer Bilder (ergänzt durch Makroaufnahmen aus der Natur) in höchst inhaltsrei-

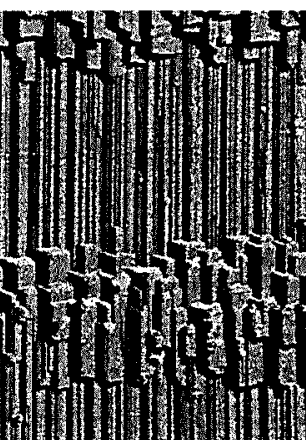
cher, aber ebenso unterhaltsamer und bildender Weise besprochen werden. Beim Durchgang durch das gang durch das Buch fallt oft nicht mehr auf, daß gleichzeitig $\mathrm{mit}$ dem Lese- und Betrachtungsvergnügen das Lernen von Sachverhalten verknüpft ist, die in vielen Wissenschaften (Physik, Chemie, Biologie vor allem Materialwissenschaft) zu den Grundkenntnissen gehören. Anhänge, unter anderem eine Zeittafel zur Entwicklung der Lichtmikroskopie und ein Literaturverzeichnis, schließen das Buch $a b$

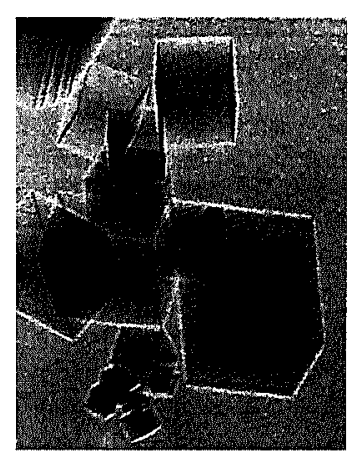

Der Deutschen Ge sellschaft für Materialkunde ist zur Herausgabe des Buchs zu gratulieren, vor allem aber auch dem Autor, dass das Buch nach - wie er selbst sagt - einer langen Odyssee - erscheinen konnte. Der Preis ist - im Vergleich zu anderen Fachbüchern und Bildbänden - als äußerst moderat zu bezeichnen, so dass sich das Buch zum Eigengebrauch ebenso wie als repräsentatives Geschenk oder Schmuckstück wissenschaftlicher Bibliotheken eignet.

Darmstadt, im Oktober 1999 H. E. Exner 